\title{
Quickly Understanding on Progressive Muscle Relaxation with Video-based Learning in Secondary School Students
}

\author{
Wan Mohamad Hafiz Bin Sulaiman ${ }^{1}$, Jumintono, ${ }^{1, *}$, Christina Fajar Sri Wahyuniati ${ }^{2}$, \\ Wiwik Suryandartiwi ${ }^{3}$, Jaka Sunardi ${ }^{2}$, Fadilah Umar ${ }^{4}$, Febri Kurnia Manoppo ${ }^{5}$, Yudanto ${ }^{2}$, \\ Jamaluddin Hos $^{6}$

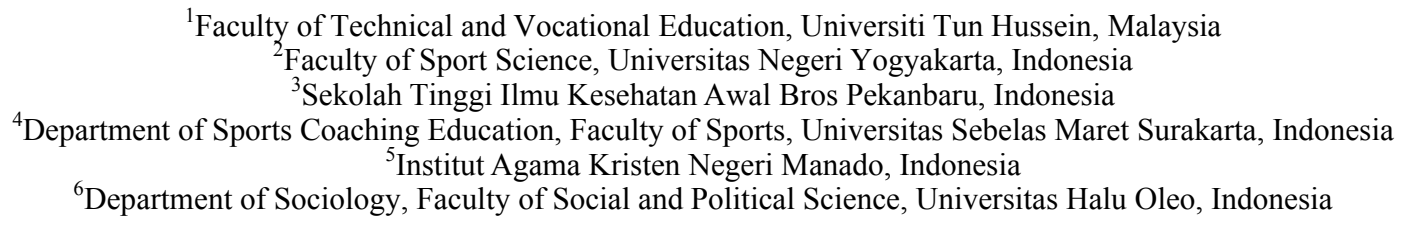

Received July 9, 2020; Revised August 21, 2020; Accepted September 11, 2020

\section{Cite This Paper in the following Citation Styles}

(a): [1] Wan Mohamad Hafiz Bin Sulaiman, Jumintono, Christina Fajar Sri Wahyuniati, Wiwik Suryandartiwi, Jaka Sunardi, Fadilah Umar, Febri Kurnia Manoppo, Yudanto, Jamaluddin Hos , "Quickly Understanding on Progressive Muscle Relaxation with Video-based Learning in Secondary School Students," International Journal of Human Movement and Sports Sciences, Vol. 8, No. 5, pp. 181 - 185, 2020. DOI: 10.13189/saj.2020.080504.

(b): Wan Mohamad Hafiz Bin Sulaiman, Jumintono, Christina Fajar Sri Wahyuniati, Wiwik Suryandartiwi, Jaka Sunardi, Fadilah Umar, Febri Kurnia Manoppo, Yudanto, Jamaluddin Hos (2020). Quickly Understanding on Progressive Muscle Relaxation with Video-based Learning in Secondary School Students. International Journal of Human Movement and Sports Sciences, 8(5), 181 - 185. DOI: 10.13189/saj.2020.080504.

Copyright $(2020$ by authors, all rights reserved. Authors agree that this article remains permanently open access under the terms of the Creative Commons Attribution License 4.0 International License

\begin{abstract}
Progressive muscle relaxation can improve students' learning performance in the classroom because it provides a good focus during classroom learning sessions in developing technical communication for educational institutions. This study aims to determine the effectiveness of video-based learning on the understanding of secondary school students related to Progressive Muscle Relaxation. The research was a quantitative descriptive method. Based on research that has been done, researchers found differences in students' understanding between before and after watching videos related to progressive muscle relaxation. In this study, respondents need to answer questions raised by researchers before viewing the video and after watching the video. The respondents in this study were only six students. The percentage of respondents who answered the question correctly after seeing the video provided by the researcher rose quite significantly. Respondents are interested in the video provided, and respondents can understand the video content they want to convey. The use of video in teaching and learning is
\end{abstract}

beneficial for students to increase their interest and demand Progressive Muscle Relaxation knowledge. Video-based learning can be implemented in teaching and learning in various fields of education. Visual lessons are more quickly remembered and understood by students. Learning to use videos can increase student's interest in learning new things.

Keywords Understanding, Progressive Muscle Relaxation, Video-based Learning, Secondary School Students

\section{Introduction}

Stress is a person who experiences physical or mental instability related to daily life. Stress also includes anxiety, fatigue, and depression due to a problem that cannot be overcome. Stress and anxiety often occur in a person, including the students. During the learning session, 
students need to complete various tasks given by the teacher. Teachers provide much work to students because they want to make sure their students understand the learning content delivered in class. Therefore, students can suffer from stress because many tasks must be completed. One positive way to deal with stress is with specialist therapy in psychiatric nursing through Progressive Muscle Relaxation (PMR), which is part of relaxation therapy (Dolbier \& Rush, 2012). Progressive muscle relaxation is a non-pharmacological therapy (Ekarini et al., 2019). Progressive muscle relaxation is a stress management technique that is widely used (Chellew et al., 2015). A continuous muscle relaxation technique is a technique that is done by stretching the muscles and then doing muscle relaxation. Some of the benefits of this technique include reducing muscle tension, anxiety, neck and back pain, building positive emotions from negative emotions. The indications for progressive muscle relaxation techniques are those with insomnia, frequent stress, anxiety, and depression.

Progressive muscle relaxation, as an additional method, can reduce anxiety and improve sleep quality (Liu et al., 2020). Progressive muscle relaxation is also very effective in reducing feelings of stress and acute anxiety (Vancampfort et al., 2011). With continuous muscle relaxation therapy, students can reduce the presence of muscle tension after doing many activities at school. Students will feel pain in their muscles after a day at school with a variety of activities and the number of assignments given. Therefore, students need to do progressive muscle relaxation to reduce pressure on their muscles. Muscles that experience fatigue or pain will make students unable to focus in class for learning sessions. Relaxation can adjust the hypothalamus reaction with the parasympathetic nerve. These conditions allow the body to reduce heart rate, blood pressure, metabolism, and respiratory rate and lower oxygen use and muscle tension (Feldman et al., 2010). Student learning performance deteriorates and will result in students trapped in high-stress situations.

Students can avoid the occurrence of high blood pressure and other diseases with PMR. This condition causes the activities carried out to reduce the pulse and give rest to the body. Students need to take good care of their health so that they do not suffer from dangerous diseases that can affect their lives. Energy-efficient use is manifested as lower $\mathrm{VO} 2$, lower heart rate, and more moderate physical consumption seen in response to intense exercise accessible to physical strategies such as spiky or with psychological approaches such as progressive muscle relaxation (Maimunah \& Hashim, 2016). Students must practice this progressive muscle relaxation to reduce the risk of hypertension and other dangerous diseases. This continuous muscle relaxation activity also increases circulation throughout the body and increases the body's resistance to viruses and bacteria that enter the institution. Progressive muscle relaxation can reduce anxiety and can increase endurance. Progressive muscle relaxation is beneficial to give rise to calm, comfortable, and relaxed responses (Sulidah et al., 2016).

Progressive muscle relaxation (PMR) is a systematic technique for achieving a level or state of total relaxation in the muscles. This activity involves the use of the whole body to reduce heart rate and relax muscles. A technique used to teach patients to relax muscles through a two-step process. At PMR, the patient first makes movements so that the muscles contract and hold tension. Second, they release all tension and focus on the sensation of relaxation (Lauche et al., 2013). Therefore, students need to do progressive muscle relaxation activities. Progressive muscle relaxation can give students many benefits and overcome problems that occur in students. Besides, students who practice this activity can also improve their learning performance in the classroom because they will provide good focus during the learning sessions in class. In addition, developing technical communication is very important for educational institutions (Jamaludin et al., 2019).

\section{Methodology}

The research method used in this study was a quantitative descriptive method in which researchers look for differences between before and after viewing videos related to progressive muscle relaxation. Quantitative methods are a way of approach to quantitative data involving numerical measurements (Mustafa et al., 2020). Descriptive statistics refer to the collection, submission, description, analysis, and interpretation of data collection (Franzese \& Iuliano, 2018). Respondents were physical education students at the Abu Bakar Temerloh Vocational School to respond to the questions given. The number of respondents selected was only six students. This study uses SPSS 23 to analyze the data obtained.

The research instrument is a series of questions that researchers have given to respondents. There are five questions related to progressive muscle relaxation (PMR) given to six students, namely about how well-positioned to do progressive muscle relaxation and which parts of the body need to be done progressive muscle relaxation. A series of questions is given to students via Google forms. A set of questions is given to students before they can see the video provided by the researcher. Students must answer the questions posed without seeing the video. They will then see videos related to progressive muscle relaxation supplied by researchers. After that, students answer back all questions given by researchers after watching the video.

\section{Results and Discussion}

In this section, researchers will tell the results of the survey conducted to respondents. The results of this study will illustrate the answers of respondents before and after seeing the video. 
Table 1. Respondent Survey Results

\begin{tabular}{|c|c|c|c|c|c|c|}
\hline \multirow{2}{*}{ No. } & \multirow{2}{*}{ Question } & \multirow{2}{*}{$\begin{array}{l}\text { Answer } \\
\text { Choice }\end{array}$} & \multicolumn{2}{|c|}{ Pre-Test } & \multicolumn{2}{|c|}{ Post-Test } \\
\hline & & & Frequency & Percentage & Frequency & Percentage \\
\hline \multirow{3}{*}{1} & \multirow{3}{*}{$\begin{array}{c}\text { Questions 1. What is Progressive Muscle } \\
\text { Relaxation (PMR)? }\end{array}$} & Yes & 0 & 0 & 19 & 83.3 \\
\hline & & No. & 26 & 100.0 & 7 & 16.7 \\
\hline & & Total & 26 & 100.0 & 26 & 100.0 \\
\hline \multirow{3}{*}{2} & \multirow{3}{*}{$\begin{array}{l}\text { Questions } 2 . \text { What is the function of using } \\
\text { progressive muscle relaxation? }\end{array}$} & Yes & 21 & 66.7 & 26 & 100.0 \\
\hline & & No & 5 & 33.3 & 0 & 0 \\
\hline & & Total & 26 & 100.0 & 26 & 100.0 \\
\hline \multirow{3}{*}{3} & \multirow{3}{*}{$\begin{array}{l}\text { Questions } 3 \text {. When is the best time to do } \\
\text { progressive muscle relaxation? }\end{array}$} & Yes & 22 & 66.7 & 26 & 100.0 \\
\hline & & No & 4 & 33.3 & 0 & 0 \\
\hline & & Total & 26 & 100.0 & 26 & 100.0 \\
\hline \multirow{3}{*}{4} & \multirow{3}{*}{$\begin{array}{l}\text { Questions } 4 \text {. What is an excellent position to do } \\
\text { progressive muscle relaxation }\end{array}$} & Yes & 3 & 16.7 & 24 & 83.3 \\
\hline & & No & 23 & 83.3 & 2 & 16.7 \\
\hline & & Total & 26 & 100.0 & 26 & 100.0 \\
\hline \multirow{3}{*}{5} & \multirow{3}{*}{$\begin{array}{l}\text { Questions } 5 \text {. Which part needs to be started to } \\
\text { perform progressive muscle relaxation? }\end{array}$} & Yes & 13 & 50 & 26 & 100 \\
\hline & & No & 13 & 50 & 0 & 16.7 \\
\hline & & Total & 26 & 100 & 26 & 100 \\
\hline
\end{tabular}

Based on table 1, the first question above, the students do not get the right answer before watching the video provided by researchers. Therefore, the table can show six learning frequencies equal to $100 \%$. Respondents did not know about progressive muscle relaxation and were not exposed to progressive muscle relaxation. After the respondent sees the video given by the researcher about progressive muscle relaxation, the respondent can answer the question correctly. Thus, the percentage of students who answered the questions precisely increased, a table showing five respondents able to answer correctly $83.3 \%$. Researchers have stated the video determines muscle relaxation. While one respondent mistakenly answered $16.6 \%$. This student is because respondents did not focus on the video. After all, the definition of muscle relaxation was mentioned at the beginning of the video.

Based on table 1,in the second question, the chart shows the results showing four respondents who answered correctly together with $66.7 \%$ without seeing the video. The answer given in the subject is as much as the word itself. Meanwhile, two respondents failed to answer correctly at $33.3 \%$. These respondents are less involved in co-curricular activities. After responding to the video provided, the percentage of respondents who responded successfully increased to six respondents with $100 \%$ success. This question is easy to understand and closely related to the fact that the item was written.

Based on table 1, the third question shows the results of two respondents who managed to answer correctly $33.3 \%$ without seeing the video. This is because respondents are given choices to answer questions. Therefore, the respondent guessed the answer correctly. Meanwhile, four respondents failed to answer correctly, which is equivalent to $66.7 \%$ because they did not know the progress of muscle relaxation. After responding to the video provided, the percentage of respondents who responded correctly increased to five respondents, with $83.3 \%$. In the video provided, it is mentioned that the right time for progressive muscle relaxation. Meanwhile, one respondent failed to answer correctly, with $16.7 \%$. Respondents are confused by the choice of answers, which is almost exactly the original answer.

Based on table 1. the fourth question shows the results of only one respondent who answered correctly, equivalent to $16.7 \%$ without seeing the video. These respondents can guess the answer correctly without knowing about progressive muscle relaxation. Meanwhile, five respondents failed to answer correctly, equivalent to $83.3 \%$ because they had not seen the video provided by the researcher. After responding to the video provided, the percentage of respondents who responded correctly increased to five respondents, with $83.3 \%$. This condition is because, in the video provided, we have shown how to do progressive muscle relaxation correctly. Meanwhile, one respondent failed to answer correctly with $16 \%$. The respondents do not understand the movements made in the video.

Based on table 1, the fifth question shows the results of five questions three respondents who answered correctly, and three respondents failed to answer correctly at $50.0 \%$ without seeing the video. Respondents understood a little about progressive muscle relaxation through the questions asked. After responding to the video provided, the percentage of respondents who responded correctly increased to 6 respondents with $100.0 \%$ success. In the video provided, researchers have shown how to do 
progressive muscle relaxation correctly.

Progressive muscle relaxation significantly benefits humanity. Progressive Muscle Relaxation (PMR) is a systematic technique that can be used to achieve deep relaxation conditions and has been shown to increase anxiety, depression, and various medical and psychiatric illnesses (Zhao et al., 2012). Therefore, this activity is highly recommended to be carried out by all levels of society to ensure that the community can live healthy and safe. There is evidence of the use of progressive muscle relaxation for the general population as an effective treatment for sleep problems. However, little evidence exists to support the use of PMR for players (McCloughan et al., 2016). This activity for progressive muscle relaxation is also natural to do and is easy to formulate beforehand because it does not require expensive equipment. All interventions were carried out in a private space with sufficient light and warmth to make patients feel relaxed during the study to conduct PMR exercises (Dikmen \& Terzioglu, 2019).

This research also found that learning through technology was very useful for students. There was an increase in all questions answered after respondents saw the video provided to answer questions raised by researchers. Learning to use this video can attract students' interest in learning something new. Results (Mendoza et al., 2015), revealed that learning to use video is very useful in increasing students' effectiveness. At present, the use of technological tools is very useful in communicating information because, through this advanced technology tool, information can be transmitted quickly and easily. Digital cameras and mobile cameras have become popular in our daily lives (Duan et al., 2012). The use of video as a type of computer-oriented communication can be easily accessed through the internet network. The internet is a global computer network that facilitates and accelerates access to the distribution of information and knowledge (learning materials) so that the content in the teaching and learning process can always be updated (Muhson, 2010).

Although the presence of technology does not guarantee equality and accessibility in learning, it can increase students' knowledge in various fields. Forms of development and changes in information technology can change the habits of community activities, no exception in the world of education (Divayana et al., 2016). With the development of the internet, and the availability of video capture devices such as digital cameras, cellphones with cameras, digital video collection sizes are fast on the internet (Li et al., 2009). Based on research conducted by (Richard et al., 2018), it is known that video learning has experienced an increase in interest over the past few years. All students have access to resources, information, and things they want to know regardless of their geographical location. This access will make it easier for students to learn and gain various knowledge. Interactive video technology has become an essential component in the teaching and learning process, in part because of developments in theoretical learning, such as teaching and learning (Kumar, 2010). The role of technology also enables better communication, sharing of resources, and better practices to improve knowledge for students. This opportunity is an excellent time and progress for the use of technology to support learning.

\section{Conclusions}

Video-based learning can be implemented in teaching and learning in various fields of education, including teaching PMR techniques. The results of this study indicate that video teaching is beneficial for students. There was an increase in all questions answered after the respondent saw the video provided. The visual lesson will be more quickly remembered and understood by students. Besides, learning to use video can encourage students' interest to learn new things.

\section{Acknowledgments}

The author would like to thank Research Fund E15501, Research Management Centre, UTHM for its support and fund of this research.

\section{REFERENCES}

[1] Chellew, K., Evans, P., Fornes-Vives, J., Pérez, G., \& Garcia-Banda, G. (2015). The effect of progressive muscle relaxation on daily cortisol secretion. Stress, 18(5), 538-544. https://doi.org/10.3109/10253890.2015.1053454

[2] Dikmen, H. A., \& Terzioglu, F. (2019). Effects of Reflexology and Progressive Muscle Relaxation on Pain, Fatigue, and Quality of Life during Chemotherapy in Gynecologic Cancer Patients. Pain Management Nursing. https://doi.org/10.1016/j.pmn.2018.03.001

[3] Divayana, D. G. H., Suyasa, P. W. A., \& Sugihartini, N. (2016). Pengembangan Media Pembelajaran Berbasis Web Untuk Matakuliah Kurikulum dan Pengajaran di Jurusan Pendidikan Teknik Informatika Universitas Pendidikan Ganesha. Jurnal Nasional Pendidikan Teknik Informatika (JANAPATI), 5(3), 149. https://doi.org/10.23887/janapati.v $5 \mathrm{i} 3.9922$

[4] Dolbier, C. L., \& Rush, T. E. (2012). Efficacy of abbreviated progressive muscle relaxation in a high-stress college sample. International Journal of Stress Management. https://doi.org/10.1037/a0027326

[5] Duan, L., Xu, D., Tsang, I. W. H., \& Luo, J. (2012). Visual event recognition in videos by learning from web data. IEEE Transactions on Pattern Analysis and Machine Intelligence. https://doi.org/10.1109/TPAMI.2011.265

[6] Ekarini, N. L. P., Heryati, H., \& Maryam, R. S. (2019). 
Pengaruh Terapi Relaksasi Otot Progresif terhadap Respon Fisiologis Pasien Hipertensi. Jurnal Kesehatan, 10(1), 47. https://doi.org/10.26630/jk.v10i1.1139

[7] Feldman, G., Greeson, J., \& Senville, J. (2010). Differential effects of mindful breathing, progressive muscle relaxation, and loving-kindness meditation on decentering and negative reactions to repetitive thoughts. Behaviour Research and Therapy, 48(10), 1002-1011. https://doi.org/10.1016/j.brat. 2010.06.006

[8] Franzese, M., \& Iuliano, A. (2018). Descriptive statistics. In Encyclopedia of Bioinformatics and Computational Biology: ABC of Bioinformatics. https://doi.org/10.1016/B978-0-12809633-8.20354-3

[9] Jamaludin, K. A., Alias, N., DeWitt, D., \& Abdul Razzaq, A. R. (2019). Framework for Technical Communication Skills Content Development for Students in Malaysian Vocational Colleges: A Fuzzy Delphi Study. Journal of Technical Education and Training, 11(4), 36-44. https://doi.org/10.30 $880 /$ jtet.2019.11.04.005

[10] Kumar, D. D. (2010). Approaches to interactive video anchors in problem-based science learning. Journal of Science Education and Technology.https://doi.org/10.1007/ s10956-009-9154-6

[11] Lauche, R., Materdey, S., Cramer, H., Haller, H., Stange, R., Dobos, G., \& Rampp, T. (2013). Effectiveness of Home-Based Cupping Massage Compared to Progressive Muscle Relaxation in Patients with Chronic Neck Pain-A Randomized Controlled Trial. PLoS ONE.https://doi.org/10 .1371/journal.pone. 0065378

[12] Li, Y., Lu, J., Zhang, Y., Li, R., \& Zhou, B. (2009). A novel video annotation framework based on video object. IJCAI International Joint Conference on Artificial Intelligence. https://doi.org/10.1109/JCAI.2009.32

[13] Liu, K., Chen, Y., Wu, D., Lin, R., Wang, Z., \& Pan, L. (2020). Effects of progressive muscle relaxation on anxiety and sleep quality in patients with COVID-19. Complementary Therapies in Clinical Practice, 39. https://doi.org/10.1016/j.ctcp.2020.101132

[14] Maimunah, S. M. P. S., \& Hashim, H. A. (2016). Differential effects of 7 and 16 groups of muscle relaxation training following repeated submaximal intensity exercise in young football players. Perceptual and Motor Skills. https://doi.org/10.1177/0031512515625383

[15] McCloughan, L. J., Hanrahan, S. J., Anderson, R., \& Halson, S. R. (2016). Psychological recovery: Progressive muscle relaxation (PMR), anxiety, and sleep in dancers. Performance Enhancement and Health. https://doi.org/10.1 016/j.peh.2015.11.002

[16] Mendoza, G. L. L., Caranto, L. C., \& David, J. J. T. (2015). Effectiveness of Video Presentation to Students' Learning. International Journal of Nursing Science, 5(2), 81-86. https://doi.org/10.5923/j.nursing.20150502.07

[17] Muhson, A. (2010). Pengembangan Media Pembelajaran Berbasis Teknologi Informasi. Jurnal Pendidikan Akuntansi Indonesia, 8(2). https://doi.org/10.21831/jpai.v8i2.949

[18] Mustafa, M. Z. Bin, Nordin, M. N. Bin, \& Abdul Razzaq, A. R. Bin. (2020). Structural equation modelling using AMOS: Confirmatory factor analysis for taskload of special education integration program teachers. Universal Journal of Educational Research, 8(1), 127-133. https://doi.org/10. 13189/ujer.2020.080115

[19] Richard, A., Kuehne, H., Iqbal, A., \& Gall, J. (2018). NeuralNetwork-Viterbi: A Framework for Weakly Supervised Video Learning. Proceedings of the IEEE Computer Society Conference on Computer Vision and Pattern Recognition, 7386-7395. https://doi.org/10.1109/C VPR.2018.00771

[20] Sulidah, Yamin, A., \& Diah Susanti, R. (2016). The Effect of Progressive Muscle Relaxation Exercise towards Older People's Quality of Sleep. Jurnal Keperawatan Padjadjaran, v4(n1), 11-20. https://doi.org/10.24198/jkp.v4n1.2

[21] Vancampfort, D., De Hert, M., Knapen, J., Maurissen, K., Raepsaet, J., Deckx, S., Remans, S., \& Probst, M. (2011). Effects of progressive muscle relaxation on state anxiety and subjective well-being in people with schizophrenia: A randomized controlled trial. Clinical Rehabilitation, 25(6), 567-575. https://doi.org/10.1177/0269215510395633

[22] Wang, F. Z., Luo, D., Kanb, W., \& Wang, Y. (2015). Combined Intervention with Education and Progressive Muscle Relaxation on Quality of Life, Functional Disability, and Positive Symptoms in Patients with Acute Schizophrenia. Journal of Alternative and Complementary Medicine. https://doi.org/10.1089/acm.2014.0128

[23] Zhao, L., Wu, H., Zhou, X., Wang, Q., Zhu, W., \& Chen, J. (2012). Effects of progressive muscular relaxation training on anxiety, depression, and quality of life of endometriosis patients under gonadotrophin-releasing hormone agonist therapy. European Journal of Obstetrics and Gynecology and Reproductive Biology. https://doi.org/10.1016/j.ejogrb. 2012.02.029 